American Journal of Environmental Sciences 7 (1): 75-81, 2011

ISSN 1553-345X

(C) 2010 Science Publications

\title{
An Expert System Applied in Construction Water Quality Monitoring
}

\author{
${ }^{1}$ Leila Ooshaksaraie and ${ }^{2}$ Noor Ezlin Ahmad Basri \\ ${ }^{1}$ Department of Environment, Faculty of Natural Resources, \\ Islamic Azad University, Lahijan Branch, Guilan, Iran \\ ${ }^{2}$ Department of Civil and Structural Engineering, \\ Faculty of Engineering and Built Environment, \\ University Kebangsaan Malaysia, \\ 43600 UKM Bangi, Selangor Darul Ehsan, Malaysia
}

\begin{abstract}
Problem statement: An untoward environmental impact of urban growth in Malaysia has been deterioration in a number of watercourses due to severe siltation and other pollutants from the construction site. Water quality monitoring is a plan for decision makers to take into account the adverse impacts of construction activities on the receiving water bodies. It is also a process for collecting the construction water quality monitoring, baseline data and standard level. Approach: In recent years, expert systems have been used extensively in different applications areas including environmental studies. In this study, expert system software -CWQM- developed by using Microsoft Visual Basic was introduced. CWQM to be used for water quality monitoring during construction activities was designed based on the legal process in Malaysia. Results: According to the water quality monitoring regulation enacted in Malaysia, construction activities require mandatory water quality monitoring plans duly approved by Department of Environment before staring activities. CWQM primarily aims to provide educational and support system for water quality monitoring engineers and decision-makers during construction activities. It displays water quality monitoring plan in report form, water sampling location in GIS format and water quality monitoring data in graph. Conclusion: When the use of CWQM in construction water quality monitoring becomes widespread, it is highly possible that it will be benefited in terms of having more accurate and objective decisions on construction projects which are mainly focused on reducing the stormwater pollution.
\end{abstract}

Key words: Artificial intelligent system, geographical information system, storm water pollution prevention, regulatory requirements, pollution mitigation measures, monitoring plan, organic material, Best Management Practices (BMPs), National Water Quality Standards (NWQS), Dissolved Oxygen (DO), Total Suspended Solid (TSS)

\section{INTRODUCTION}

Expansion of urban areas is the main causes of land use change in the developing countries (Solaimani et al., 2009). In urban development, construction sector plays major role in every country. It provides the direct means to the development and is, at the same time, a major polluter of the environment (Baris and Erik, 2000). Rapid development and expansion of construction activities without carrying-out proper application of technology might impose adverse impacts on the quality of the water body (Safaian et al., 2004). Therefore, it is important to plan Best Management Practices (BMPs) by considering not only cost efficiency but also the appropriate management of water and soil (Parsakhoo et al., 2009). It is common sense that water pollution may be due to industrial effluents such as exhaust fumes and gases liquid or solid wastes (Benmenni and Benrachedi, 2010). But in the immediate future, construction activity will continue to produce the most adverse impact on the receiving water quality through the discharge of its pollutants. Construction activities can disturb soil and travels down from a construction site that eventually ends up in rivers. Erosion is one of the most significant forms of land degradation (Solaimani et al., 2009). Sediment, which results from the excessive erosion of disturbed soils, is the primary pollutant of concern.

Corresponding Author: Leila Ooshaksaraie, Department of Environment, Faculty of Natural Resources, Islamic Azad University, Lahijan Branch, Guilan, Iran 
However, other pollutants such as construction chemicals, nutrients, soil additives, pesticides, metals, oil and grease and miscellaneous wastes are also of concern at construction sites (DID, 2001). Further, it can increase the inputs of organic material into streams and reduces the amount of oxygen in receiving water bodies (EIA, 2007). Thus, construction activities can be detrimental to water resources, which can become critical in some areas (Baris and Erik, 2000). Continuous degradation of water body has caused concerns for people who live on the coast of water body (Safaian et al., 2004). Therefore, protection of surface water from pollution has received a high priority since many countries have suffered from considerable deterioration in the quality of their water resources (Vrtacnik et al., 1992).

Water resources are essential and play a significant role in the development processes (Al-Dakheel et al., 2009). Water quality monitoring is proposed for construction projects to provide assurance of compliance with regulatory requirements. It is also recommended to ensure that water quality degradation does not occur as a result of the construction activities (RTA, 2010). There are three significant steps involved in the water quality monitoring plan during construction activities:

- Information about site location

- Consideration of all suitable water quality parameters to be affected from the site

- Evaluation of the collected data in an accurate way

This evaluation is completed before decisions related to the pollution mitigation measures are taken and it is a challenging process requiring intense data, experience and knowledge. Water quality is continuously monitored to meet related regulations. Assessing and preparing the water quality monitoring plan are the most important and time-consuming task that relates to various information, data, domain law, expert knowledge and experience in terms of construction activities, environmental and receiving water protection. Therefore, there needs to be a support system for collecting, analyzing and reporting information (Say et al., 2007; Muthusamy and Ramalingam, 2003). Expert system is a computer based system utilizes data and model to support decision maker for solving unstructured problems (Hartati and Sitanggang, 2010). It is promising technology that manages data and information and provides the required expertise (Say et al., 2007). It thus seem well suited to many of tasks associated with water quality management.

Jin presented GIS-based expert system for onsite stormwater management (Jin et al., 2006). Oprea also contributed an expert system to analyse soil, water and air pollution. Ghani demonstrated the use of knowledge-based system for river water quality management (Ghani et al., 2009).

CWQM introduced in this study was designed for construction sites and it aims to inform the project owner, the consultants and decision-makers at the water quality monitoring plan preparing in the most accurate, the newest and the fastest way.

\section{MATERIALS AND METHODS}

Water quality monitoring and construction activities in Malaysia: The last decades the coastal area many pressures are taken on the man-made activities (Economou, 2009). Urban development is particularly rapid in Malaysia. An untoward environmental impact of urban growth in Malaysia has been the frequent occurrence of excessive soil losses from construction sites. There has also been deterioration in a number of watercourses due to severe siltation and other pollutants from the site (DID, 2001). Therefore, in Malaysia, Department Of Environment (DOE) has proposed preparing water quality monitoring plan during construction activities. Monitoring has four steps: (1) identifying sampling stations, (2) identifying sampling frequency, (3) describing water quality monitoring parameters, (4) assessing water quality condition compliance with regulatory requirements. Then according to the regulation and assessment results, plan is defined to regulate river water quality by pollution control and mitigation measures on construction site referring to inspect Best Management Practices (BMPs).

The classification of Malaysian rivers according to their pollution level is defined by five categories as presented in Table 1 (EIA, 2007). Changes in the water quality of the river can be evaluated against National Water Quality Standards (NWQS) for various beneficial uses of water. The classification of rivers and the establishment of acceptable water quality standards allow better evaluation of the impact on river water quality The target of water quality monitoring is specified by the Malaysian Local Authority. At least, impact is monitored by reference to water quality parameters such as Biochemical Oxygen Demand (BOD), Chemical Oxygen Demand (COD), Dissolved Oxygen (DO), Total Suspended Solid (TSS), $\mathrm{pH}$, Amonical Nitrogen $\left(\mathrm{NH}_{3}-\mathrm{N}\right)$, oil and grease, E-coli and temperature. The amount of these parameters of river water quality would indicate the amount of pollutants discharged from the site into the receiving water recourses. 
Table 1: Water classes and uses

\begin{tabular}{|c|c|}
\hline Class & Uses \\
\hline Class I & $\begin{array}{l}\text { Water supply- practically no treatment necessary } \\
\text { Fishery- very sensitive aquatic species. }\end{array}$ \\
\hline Class IIA & $\begin{array}{l}\text { Water supply- conventional treatment required. } \\
\text { Fishery- sensitive aquatic species. }\end{array}$ \\
\hline Class IIB & Recreational use with body contact. \\
\hline Class III & $\begin{array}{l}\text { Water supply- extensive treatment required. } \\
\text { Fishery- common, of economic value and } \\
\text { tolerant species; Livestock drinking. }\end{array}$ \\
\hline Class IV & Irrigation. \\
\hline Class V & None of the above. \\
\hline
\end{tabular}

Table 2: DOE water quality index classification

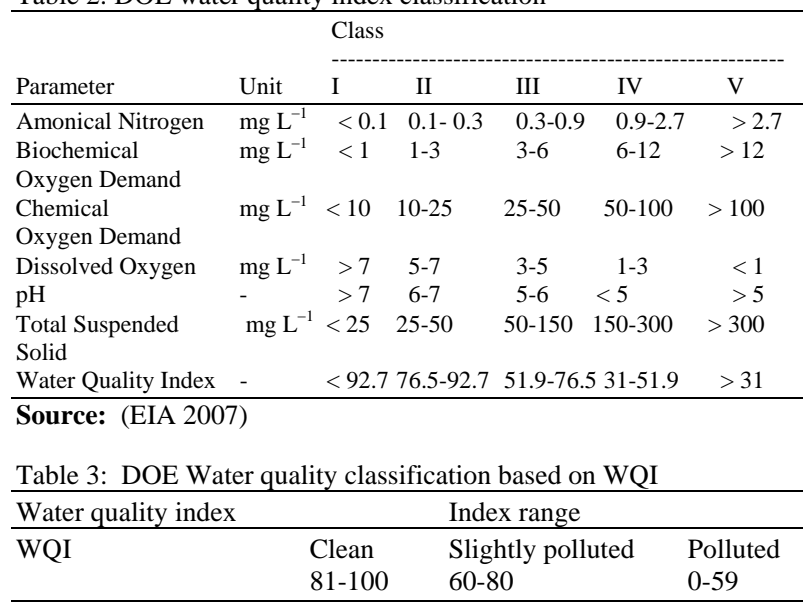

Source: (EIA 2007)

DOE-Water Quality Index (WQI) is used to identify the status of river water quality according to the system adopted by the Malaysian DOE (David Rapport, 2003). The index is established based on the results of an opinion poll of a panel of experts who determined the choice of parameters and weights assigned to each chosen water quality parameter (David Rapport, 2003). Six water quality parameters (DO, $\mathrm{pH}, \mathrm{BOD}, \mathrm{COD}$, TSS and $\mathrm{NH}_{3}$ N) are used to calculate this index (David Rapport, 2003). Calculations are performed on their sub-indexes whose values are obtained from a series of equation. These are best-fit equations obtained from rating curves (Yusuf et al., 2003). The sub-indexes for these parameters are named SIDO, SIBOD, SICOD, SIAN, SISS and SIPH. The Equation used to calculate WQI is as follows (David Rapport, 2003):

$\mathrm{WQI}=0.22 \times \mathrm{SIDO}+0.19 \times \mathrm{SIBOD}+0.16 \times \mathrm{SICOD}+$ $0.15 \times$ SIAN $+0.16 \times$ SISS $+0.12 \times$ SIPH

WQI classification and water quality classification based on WQI are presented in Table 2 and 3.

It is a fact that construction activities cause water quality problems. Mainly for this reason, the reliability and quality of water quality monitoring plans have great importance in the implementing housing projects in terms of having the least negative impact on receiving water bodies. The reliability and quality of water quality monitoring plans can be increased by having this kind of soft-wares which cover the information on the legal water quality monitoring process of the country. To mitigate these problems, an expert system, "CWQM", was designed for the objective minimisation river pollution from construction sites through:

- Identification of selected pollutants with probable adverse impacts

- Diagnosis of the pollution sources from the site

- Planning action to cope with indicated problem from the construction site

- Providing advice on ways to reduce pollution at construction site

"CWQM" attempts to provide water pollution control measures based on the experts knowledge, lowest cost, highest efficiency, durability and availability of technical expertise.

CWQM framework: Expert system simulates the learning, reasoning, communication and action processes of a human expert in a given area of science. In this way, it gives a consultant that can substitute the human expert systems with reasonable guaranties of success. These characteristics allow expert system to store data and knowledge, learn from experience and existing data, draw logical conclusions, make decisions, communicate with other human experts or expert systems, explain why decision have been made and take actions as a consequence of all the above (Amiruddin and Atiq, 2009). The expert system has been successfully applied in various domains, such as engineering, water quality management, agricultural management, environmental protection, waste management, wastewater treatment and urban design (Liao, 2005). Therefore, it seem well suited to water quality monitoring study. For detect the problem and guide the user, a system needs to develop through the diagnostic and advisory process that knowledge is represented by rules (Negnevitsky, 2005). The simplest way for executing the system is to explicit knowledge directly from experts, rule by rule (Karnib et al., 2002). This system usually requires explanation facilities to justify their solutions to the user. Such facilities are an essential component of expert system (Negnevitsky, 2005). Therefore, a rule-based expert 
Table 4: CWQM characteristics

\begin{tabular}{ll}
\hline Items & Characteristics \\
\hline Domain & $\begin{array}{l}\text { River pollution prevention during } \\
\text { construction activities } \\
\text { Tnowtbooks, manuals, research } \\
\text { publications, guidelines, expertise } \\
\text { Interview with experts, certainty factor }\end{array}$ \\
$\begin{array}{l}\text { Knowledge } \\
\text { acquisition technique } \\
\begin{array}{l}\text { Knowledge } \\
\text { representation technique }\end{array}\end{array}$ & Rules \\
$\begin{array}{l}\text { Inference engine } \\
\text { Explanation facility }\end{array}$ & $\begin{array}{l}\text { Forward chaining } \\
\text { Relation between regulations and } \\
\text { expertise analysis }\end{array}$ \\
$\begin{array}{l}\text { Development method } \\
\text { Development tool }\end{array}$ & $\begin{array}{l}\text { Prototype } \\
\text { Visual basic }\end{array}$ \\
Objectives & $\begin{array}{l}\text { Visual basic } \\
\text { To help in preventing river pollution } \\
\text { from construction site }\end{array}$ \\
\hline
\end{tabular}

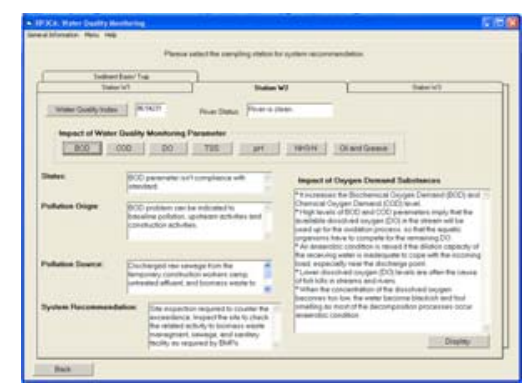

Fig. 1: The result report

system and forward chaining inference mechanism are used to develop the CWQM.

In development phase of the CWQM, few meeting were organized to consult with five experts whom three experts were from university, while the others, from DOE and consultant. Experts diagnose critical factors including expert experience and associated regulations that derive the control measures for water quality monitoring on construction sites.

The law and experts' evaluation processes regarding water quality monitoring are considered to construct the expert decision model and subsequently develop the inference engine. Certainty factor is used to measure the expert belief or disbelief the system rules.

CWQM is developed by using Microsoft Visual Basic 6 (VB). It enables users to enter information requested and the system then assesses data for the inference mechanism to derive the system recommendation and results. GIS (Geographic Information System) tool is one of the most powerful devices for storing, modeling and analysis of geographic data (Khojastehfar et al., 2009). For this reason, the interface of CWQM utilizes Geographic Information System (GIS) functions as a supportive component to display spatial maps for visualization of water quality monitoring stations. It is more effective and efficient that is able to fulfill the need for mapping and planning (Hasmadi et al., 2010). In addition CWQM provides explanation facility to explain how the system arrived at certain results and to justify the matched rules based on accuracy grade. A sample screen of displaying system recommendation is shown in Fig. 1. The characteristics of the CWQM are presented in Table 4 that states domain, knowledge resources, knowledge acquisition technique, knowledge representation technique, inference engine, explanation facility, development method, development tool, user interface and objectives of the CWQM.

The developed CWQM is tested and evaluated in a variety of scenarios and the test outputs generated at each stage are checked, validated and revised. Modifications, improvements and testing of system are continuous processes that take place in CWQM development.

\section{RESULTS}

CWQM is designed in such a way that a series of general and specific questions can be answered by a proposed conceptual structure of the relational database such as:

- Where is the best location for water quality monitoring during construction activities?

- What are the suitable parameters for water quality monitoring?

- What is WQI level and river status?

- What is the level of river pollution?

- What is the adverse impact of pollutant on surface water?

- Which type of construction activities can be identified as possible sources of pollination at a monitoring point?

- What is the probable source of pollutant from the site?

- How can pollution be reduced at its source onsite?

System enables to compare the monitoring data of the given river pollution levels with baseline data at monitoring point and standard level. Therefore, CWQM can check three hypotheses:

- Hypothesis 1: The pollution is caused by discharges of pollutants from the construction site

- Hypothesis 2: The pollution is caused by discharges of pollutants from other area located along the river sites

- Hypothesis 3: The river was already polluted 
The goal is to identify, within a given region of river water pollution, the most probable construction activities as pollution sources and to give proposal on the implementation of BMPs in order to minimize the river water pollution level.

\section{DISCUSSION}

The content of the program consists of water quality monitoring plan during construction activities. The working system of the program is given in Fig. 2. The database, including information about water quality standard level, WQI classification, river water quality classification based on WQI and adverse impact of pollutants on surface water has been prepared.

The program primarily aims to inform the project owners, water quality monitoring experts and decisionmakers on the following themes:

- General information about water quality monitoring plan: The program presents the user various information related to the water quality monitoring plan on construction sites:

- Information about sampling location of river with or without multiple outfalls

- Explanation about sampling parameters

- General information about the sampling frequency during periods when rainfall results in any discharge from the site and there is no rainfall

- Example report form about the water quality monitoring

- Map for sampling location in GIS format

An example was made for a construction site which is situated in the Malaysia by running the software. As a first step, after entering the information of the project's location, the construction site can be seen on screen. After the queries are completed, related result map is linked from the database and monitored on the screen to view the water quality monitoring locations (Fig. 3):

- Water Quality Index level of river: Calculation of WQI of river derived (BOD, COD, DO, TSS, $\mathrm{pH}$, $\mathrm{NH}_{3}-\mathrm{N}$ ) during construction activities by Malaysian DOE-WQI method

- River status: WQI is used to identify the status of river water quality by comparing WQI level with rating scale according to the system adopted by the Malaysian DOE

- Comparison of monitoring data with baseline data and standard level: The comparison of water

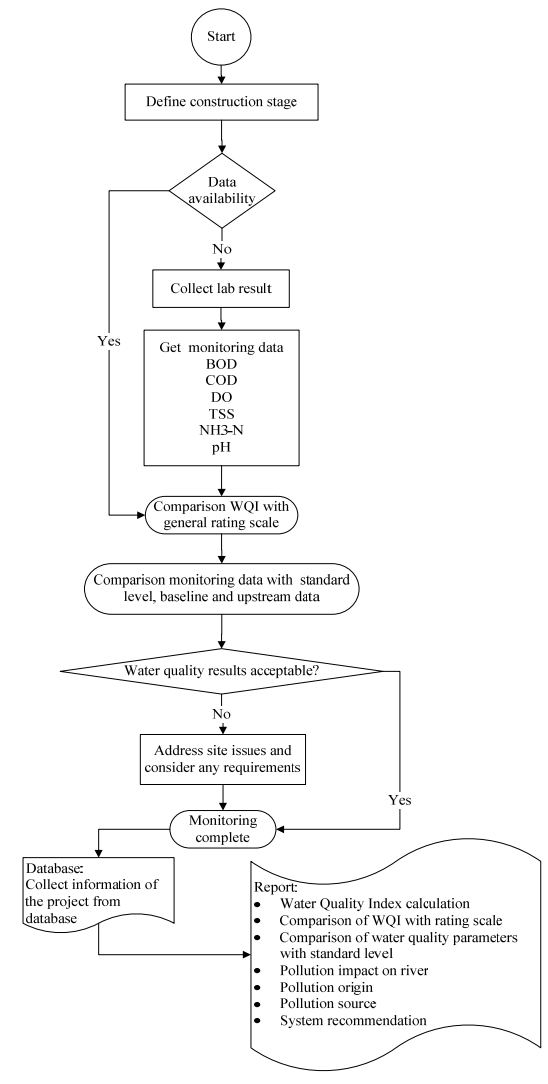

Fig. 2: General structure of CWQM

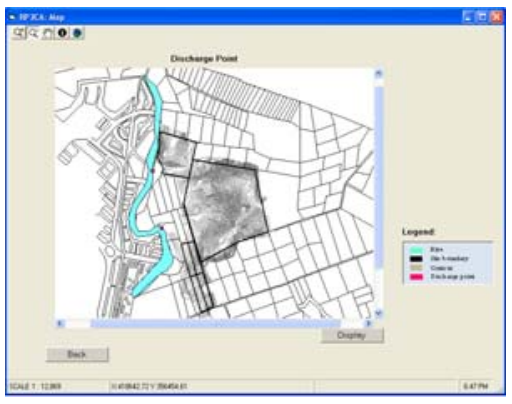

Fig. 3: Water quality monitoring location

- quality monitoring data with baseline data and standard level-stated in different legal regulations in Malaysia-is done

- Present situation of the water quality monitoring: The amount of parameters of river water quality would indicate the amount of pollutants discharged into the receiving water recourses if parameters are not compliance with standard level

- Probable effects of pollutants on receiving water bodies: The program presents adverse impacts of 
pollutants on surface water if parameters are not compliance with standard level

- Pollution source from construction site: Pollution source that indicated to the construction site is informed to the user by comparing water quality monitoring and baseline data

- Pollution mitigation measures: Finally it recommends the user on pollution prevention plan by referring to the BMPs on construction site

- System also presents all information and result about water quality monitoring plan in a report form. In addition, it displays river water quality monitoring data, baseline data and standard level in graph

\section{CONCLUSION}

Construction activities have an important share in degradation of receiving water quality in Malaysia. Therefore, water quality monitoring is needed during construction activities. In line with this, it is very essential to use the most reliable and newest method for water quality monitoring plan to be used for construction sites. CWQM may be regarded as a tool to use in water quality monitoring during construction activities in Malaysia. The most difficult phase of the study is to obtain information and expertise and transferring this knowledge and experience into the database. It will be possible to make use of the database when the data are completed as a result of the inventories about the situation of the water resources, present regulation on water quality, pollutants criteria and pollution mitigation measures in the country. Then, the database will be used about water resources protection related to the every construction site. As a result, when the use of CWQM in water quality monitoring during construction activities becomes widespread, it is highly possible that it will be benefited in terms of having more accurate and objective decisions on construction projects which are mainly focused on reducing the river pollution.

\section{ACKNOWLEDGEMENT}

The researchers are grateful to the Ministry of Science and Technology Innovation Malaysia, for the financial support of this research (01-01-02-SF0363).

\section{REFERENCES}

Al-Dakheel, Y.Y., A.H.A. Hussein, A.S.E. Mahmoudi and M.A. Massoud, 2009. Soil, water chemistry and sedimentological studies of Al Asfar evaporation Lake and its Inland Sabkha, Al Hassa Area, Saudi Arabia. Asian J. Earth Sci., 2: 1-21.

Baris, D.P. and J. Erik, 2000. Construction and environment-improving energy efficiency. LIBRIS-National Library Systems.

Benmenni, M.S. and K. Benrachedi, 2010. Impact of earthquake demolition debris on the quality of groundwater. Am. J. Applied Sci., 7: 545-550. DOI: 10.3844/ajassp.2010.545.550

Amiruddin, D. and R. Atiq, 2009. Development of knowledge-based expert system for flexible pavement design. J. Applied Sci., 9: 2372-2380. DOI: $10.3923 /$ jas.2009.2372.2380

DID, 2001. Urban Storm Water Management (MSMA). Department of Irrigation and Drainage (DID): Malaysia.

EIA, 2007. Environmental Impact Assessment (EIA) Instructional Guide. United Nations University.

Economou, A., 2009. The land uses' consequences in coastal area of faliraki and delta penaeus river in Greece. Am. J. Agric. Biol. Sci., 4: 39-48. DOI: 10.3844/ajabssp.2009.39.48

Hartati, S. and I.S.M. Sitanggang, 2010. A fuzzy based decision support system for evaluating land suitability and selecting crops. J. Comput. Sci., 6: 417-424. DOI: $10.3844 /$ jcssp.2010.417.424

Hasmadi, I.M., H.Z. Pakhriazad and F.S. Mohamad, 2010. Geographic information system-allocation model for forest path: A case study in ayer hitam forest reserve, Malaysia. Am. J. Applied Sci., 7: 376-380. DOI: 10.3844/ajassp.2010.376.380

Jin, Z., F. Sieker, S. Bandermann and H. Sieker, 2006. Development of a GIS-based expert system for onsite storm-water management. J. Water Practice Technol., DOI: 10.2166/wpt.2006.016

Karnib, A., J. Al-Hajjar and D. Boissier, 2002. An expert system to evaluate the sensitivity of urban areas to the functioning failure of storm drainage networks. J. Urban Water., 4: 43-51. DOI: 10.1016/S1462-0758(01)00063-2

Khojastehfar, E., A.S. Daryan and M.A. Assareh, 2009. Probabilistic empirical green's function method in ground motion simulation. Am. J. Eng. Applied Sci., 2 : $160-164 . \quad$ DOI: 10.3844/ajeassp.2009.160.164 
Liao, S.H., 2005. Expert system methodologies and applications-a decade review from 1995 to 2004. J. Expert Syst. Appl., 28: 93-103. DOI: 10.1016/j.eswa.2004.08.003

Muthusamy, N. and M. Ramalingam, 2003. Environmental impact assessment for urban planning and development using GIS. In: Proceedings of the 3rd International Conference on Environment and Health, Chennai, India Dec. 1517, Department of Geography, University of Madras, York University, India, Chennai, pp: 290299.

Negnevitsky, M., 2005. Artificial Intelligence: A Guide to Intelligent System. 2nd Edn., Addison-Wesley: England, ISBN: 0321204662, pp: 415.

Parsakhoo, A., S.A. Hosseini, M. Lotfalian and H. jalilvand, 2009. . Influence of Hillside Gradient on Forest Road Cross Section Components in a Loamy Clay Soil. Am. J. Applied Sci., 6: 12121216. DOI: 10.3844/ajassp.2009.1212.1216

Ghani, P.H.A., M.K. Yusoff, L.A. Manaf and M.B. Daud, 2009. Knowledge-based system for river water quality management. Eur. J. Scientific Res., 33: 153-162.
RTA, 2010. Guideline for construction water quality monitoring. Roads and Traffic Authority.

Safaian, N., M. Shokri and B. Jabbarian, 2004. Environmental impact assessment of development in the southern coast of the Caspian Sea (Northern Iran). Polish J. Environ. Stud., 13: 319-323.

Say, N.P., M. Yucela and M. Yılmazerb, 2007. A computer-based system for Environmental Impact Assessment (EIA) applications to energy power stations in Turkey: CEDINFO. Energy Policy, 35: 6395-6401. DOI: 10.1016/j.enpol.2007.08.009

Solaimani, K., S. Modallaldoust and S. Lotfi, 2009. Soil erosion prediction based on land use changes (A case in neka watershed). Am. J. Agric. Biol. Sci., 4: 97-104. DOI: 10.3844/ajabssp.2009.97.104

Vrtacnik, M., D. Dolnicar, A. Cizerle, P. Cok, and S.A. Glazar et al., 1992. Design of an Expert System for Water Pollution Determination/Prevention. Expert Syst. Appl., 5: 403-410. DOI: 10.1016/0957-4174(92)90024-M

David Rapport, 2003. Managing for Healthy Ecosystems. 1st Edn., Lewis Publishers, California ISBN-10: 1566706122, pp: 1510. 